9. Специализированные сорта и инновационные приемы производства масличного льна / Т.А. Рожмина [и др.] // Аграрный вестник Юго-Востока. 2016. - № 1-2(14-15). - С. 56-59.

Кулеватова Татьяна Борисовн $а$, канд. биол. наук, ведущий научный сотрудник лаборатории качества зерна, ФГБНУ «НИИСХ Юго-Востока». Россия.

Злобина Людмила Николаевна, канд. с.- $x$. наук, научный сотрудник лаборатории качества зерна, ФГБНУ «НИИСХ Юго-Востока». Россия.
Лящева Светлана Витальевна, канд. с.-х. наук, руководитель селекционного ицентра, ФГБНУ «НИИСХ Юго-Востока». Россия.

Андреева Любовь Владимировна, канд. с.-х . наук, ведущий научный сотрудник лаборатории качества зерна, ФГБНУ «НИИСХ Юго-Востока». Россия.

410010, г. Саратов, ул. Тулайкова, 7.

Тел.: (8452) 64-76-88.

Ключевые слова: лен масличный; вязкость суспензии; скорость изменения вязкости; вискограф; кривая набухания.

\title{
FEATURES OF THE RHEOLOGICAL PROPERTIES OF AQUEOUS SUSPENSIONS BASED ON WHOLE-GRAIN OIL FLAX
}

Kulevatova Tatyana Borisovna, Candidate of Biological Sciences, Leading Researcher, Agricultural Research Institute for South-East Region. Russia.

Zlobina Ludmila Nikolayevna, Candidate of Agricultural Sciences, Researcher, Agricultural Research Institute for SouthEast Region. Russia.

Lyascheva Svetlana Vitalievna, Candidate of Agricultural Sciences, Agricultural Research Institute for South-East Region. Russia.

Andreyeva Lyubov Vladimirovna, Candidate of Agricultural Sciences, Leading Researcher, Agricultural Research Institute for South-East Region. Russia.
Keywords: flax; viscosity of suspension; rate of viscosity change; viscograph; swelling curve.

The rheological curves of aqueous suspensions based on whole-grain flax were obtained in the experimental protocols of a Brabender viscograph in several temperature modes $\left(20,30 u 42^{\circ} \mathrm{C}\right)$ and features of swelling of the components were revealed. The quantitative intensity of some indicators of the rheograms was studied. The experimental technique at $20^{\circ} \mathrm{C}$ had the highest distinguishing ability at the varietal level. The suspension based on whole-grain flax seeds of the ITIL variety had the highest viscosity.

\section{ЭФФЕКТИВНОСТЬ ПРИМЕНЕНИЯ МИНЕРАЛЬНЫХ УДОБРЕНИЙ И БАКТЕРИАЛЬНЫХ ПРЕПАРАТОВ ПРИ ВЫРАЩИВАНИИ САФЛОРА В ЗОНЕ РИСКОВАННОГО ЗЕМЛЕДЕЛИЯ РОСТОВСКОЙ ОБЛАСТИ}

\section{РАЗУМНОВА Людмила Александровна, Донской государственный аграрный университет КАМЕНЕВ Роман Александрович, Донской государственный аграрный университет БАЛЕНКО Елена Георгиевна, Донской государственный аграрный университет}

В статье представлены результаты изучения влияния минеральных удобрений и бактериальных препаратов на урожайность и качество семян сафлора сорта Заволжский-1. Бактериальные препараты были представлены ассоциативными азотфиксаторами итаммов Мизорин, Флавобактерин, КЛ-10. В полевом опыте также были изучены варианты совместного применения минеральных удобрений и предпосевной обработки семян бактериальными препаратами. Средняя урожайность семян сафлора на опытных вариантах составила 1,03-1,22 m/га, масличность семян - 35,9-36,3 \%, сбор масла с 1 га - 337-398 к2. Установлена оптимальная доза минеральных удобрений $N_{48} P_{52}$; вносятся вразброс под предпосевную культивацию. Прибавка к контрольному варианту составила 18,4\%. Сбор масла повысился на 23,7 \%. Выявлен лучший бактериальный препарат с ассоциативными штаммами азотфиксаторов для использования на естественном фоне плодородия почвы. Это Флавобактерин. Урожайность маслосемян увеличилась на 13,6 \%, сбора масла - на 18,1\%.

Введение. В Ростовской области зерновые культуры ежегодно занимают до 80-90 \% сельскохозяйственных земельных угодий, 50-60\% отводятся озимой пшенице. Это свидетельствует о том, что структура посевных площадей отсутствует, севообороты нарушены $[6,10]$. Для решения этой проблемы в условиях рискованного земледелия Ростовской области, где лимитирующим фактором в получении стабильных и высоких урожаев полевых культур является продуктивная влага, необходимо возделывать сельскохозяйственные культуры, способные переносить засушливые ус- ловия. Одной из таких является масличная культура сафлор. Его семена содержат от 32 до 38 \% жира, урожайность достигает 2,5 т/га [8].

Сафлор не имеет конкурентов по своим адаптационным возможностям к крайне неблагоприятным погодным условиям. Это растение исключительно засухоустойчивое, прекрасно переносит дефицит влаги в отличие от подсолнечника, рапса. Засушливые годы для сафлора более благоприятны, чем годы с затяжной дождливой погодой, так как при этом у него не образуются семена [1]. Связано это и с тем, что родиной сафлора являют- 
ся Эфиопия и Афганистан [13]. Но абсолютно без почвенной влаги нельзя получить высокие урожаи маслосемян. Особенно важен период в течение вегетации растений ветвление - бутонизация [11]. Сафлор является хорошим предшественником, в том числе и для озимой пшеницы, так как уборку проводят в середине августа [14]. Культура обладает мелиоративными свойствами, то есть структурирует и улучшает почву [9].

Согласно рекомендациям «Зональные системы земледелия Ростовской области на 20132020 годы», минеральные удобрения под сафлор целесообразно вносить под основную обработку почвы, при посеве и междурядной культивации. Минеральные удобрения лучше вносить под зябь в дозе $\mathrm{N}_{45} \mathrm{P}_{60}$, а на почвах, бедных калием, - полное минеральное удобрение в дозе $\mathrm{N}_{45} \mathrm{P}_{60} \mathrm{~K}_{45}$ [5]. Но данные рекомендации даны для посевов семян сафлора широкорядным способом, в то время как в основном используют рядовой.

С каждым годом бактериальные препараты со штаммами ассоциативных азотфиксаторов находят всё большее применение. Они способствуют повышению плодородия почвы и получению высоких урожаев с меньшими затратами. В Ростовской области уже имеется опыт применения бактериальных препаратов с азотфиксаторами под арбуз, зерновое сорго, лен масличный, кукурузу на зерно. Но исследований по сафлору не проводилось.

Цель нашей работы - изучение влияния минеральных удобрений и биопрепаратов с активными штаммами ассоциативных микроорганизмов-азотфиксаторов на урожайность сафлора.

Методика исследований. Полевые опыты проводили в 2016-2018 гг. на на темно-каштановых почвах СПК «Заря» Обливского района Ростовской области в соответствии с методикой Б.А. Доспехова [4]. Климат зоны проведения исследований засушливый, умеренно континентальный. Среднегодовая сумма осадков составляет 377 мм [12]. Объектом исследований являлся сафлор сорта Заволжский-1. Оригинатор: ГНУ Нижне-Волжский НИИСХ Россельхозакадемии (Волгоградская обл.). Повторность опыта трехкратная. Пло-

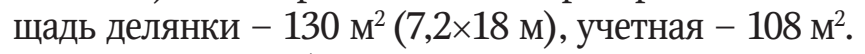
Агротехника - общпринятая для зоны [2,3].

Предшественником сафлора являлась озимая пшеница. Закладку опытов, проведение наблюдений и учетов в течение вегетации осуществляли согласно методикам опытов с удобрениями. В опыте использовали бактериальные препараты, изготовленные во Всероссийском институте сельскохозяйственной микробиологии (ВНИИСХМ), г. Санкт-Петербург, со штаммами ассоциативных азотфиксаторов: Мизорин, Флавобактерин, КЛ-10 [7]. Также использовали минеральные удобрения: аммиачную селитру $(34,6 \% \mathrm{~N})$, аммофос $\left(12 \% \mathrm{~N} 50 \% \mathrm{P}_{2} \mathrm{O}_{5}\right)$ и хлористый калий (60\% К $\mathrm{K}_{2}$ ). Перед посевом сафлора минеральные удобрения вносили вручную с последующей заделкой культиватором и при посеве сеялкой C3-3,6. Способ посева сафлора рядовой. Бактериальные препараты вносили одновременно с посевом путем обработки семян - 300 г/га. Уборку сафлора проводили поделяночно вручную с пересчетом урожайности на стандартную влажность.

Обеспеченность почвы доступными элементами питания перед посевом существенно различалась в годы проведения полевых опытов. Наименьшее содержание нитратного азота в слое почвы 0-60 см было в 2018 г. - 24,5 кг/га, в 2016 г. - 30,0 кг/га и в 2017 г. - 39,5 кг/га. В 2017 г. содержание подвижного фосфора в слое 0-40 см по градации Мачигина соответствовало очень низкой обеспеченности 8,4 мг/кг, в 2016 и 2018 гг. средней - 16,8 и 19,3 мг/кг почвы. Более наглядно различалась обеспеченность почвы обменным калием в слое 0-40 см. В 2018 г. она соответствовала средней обеспеченности 221 мг/кг (по Мачигину), в 2017 г. повышенной 360 мг/кг и в 2016 г. высокой - 421 мг/кг почвы.

Результаты исследований. Погодные условия в годы проведения полевых опытов существенно различались, что отразилось на накоплении и динамике продуктивной влаги в почве. Запас доступной влаги в метровом слое почвы перед посевом сафлора был наименьшим в 2016 г. - 83,2 мм, наибольшим в 2017 г. - 130,6 мм, в 2018 г. - 125,4 мм (см. рисунок). Это свидетельствует о неодинаковом количестве выпавших осадков за период осенне-зимнего и весеннего накопления почвенной влаги.

В течение вегетации сафлора во все годы проведения полевых опытов в метровом слое почвы отмечали резкое снижение содержания продуктивной влаги от посева до фазы цветения. В период цветение - полная спелость запас доступной влаги в метровом слое был минимальным, а почва близка к иссушению. Поэтому, безусловно, условия увлажнения оказали существенное влияние на урожай-

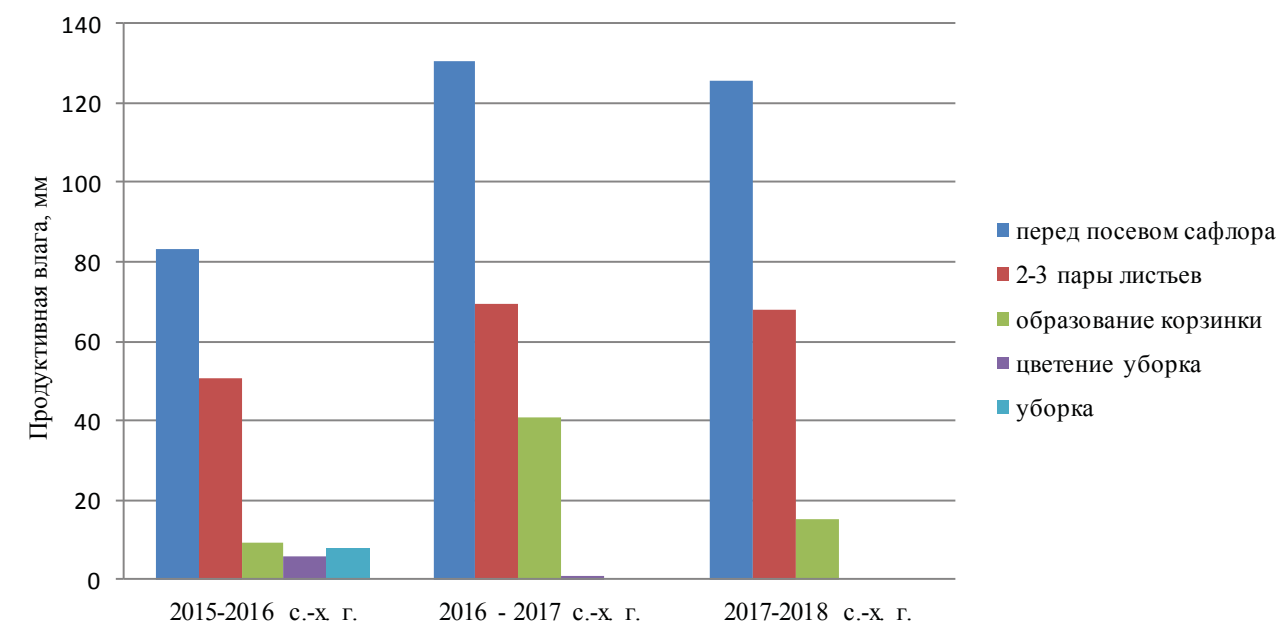

Динамика продуктивной влаги под сафлором, мм, в слое почвы 0-100 см 
ность сафлора, как на контроле, так и в вариантах с минеральными удобрениями и биопрепаратами.

В 2016 и 2018 гг. урожайность семян сафлора на контрольном варианте (без удобрений и бактериальных препаратов) была практически одинаковой и составила $0,92-0,94$ т/га, несколько больше в 2017 г. - 1,11 т/га (табл. 1).

В 2016 г., оценивая действие минеральных удобрений, применяемых под предпосевную культивацию, было получено существенное увеличение урожайности семян. Наибольшую прибавку $(0,26$ т/га, или 28,3 \%) по сравнению с контрольным вариантом отмечали на варианте с дозой $\mathrm{N}_{48} \mathrm{P}_{52}$. Применение ассоциативных азотфиксаторов в 2016 г. на естественном фоне плодородия способствовало увеличению урожайности семян сафлора только на варианте со штаммом Флавобактерин. По сравнению с контролем оно составило $21,7 \%$. Использование штамма Мизорин на фоне азотнофосфорных удобрений в дозе $\mathrm{N}_{24} \mathrm{P}_{52}$ обеспечило такую же прибавку, как на варианте со штаммом Флавобактерин на естественном фоне плодородия. Использование других штаммов на фоне минеральных удобрений было неэффективно.

В 2017 г. на фоне повышенной обеспеченности почвы обменным калием максимальный эффект получили от применения полного минерального удобрения под предпосевную культивацию в дозе $\mathrm{N}_{48} \mathrm{P}_{52} \mathrm{~K}_{48}$. Прибавка по сравнению с контрольным вариантом составила 0,26 т/га, или $23,7 \%$.

Повышение урожайности семян сафлора в 2017 г. получили в результате применения бактериальных препаратов штаммов Флавобактерин и КЛ-10 на фоне естественного плодородия почвы. Увеличение составило к контрольному варианту 0,14 т/га, или 12,6 \%. Совместное применение ассоциативных азотфиксаторов на фоне азотно-фосфорных удобрений обусловливало лишь тенденцию увеличения урожайности или снижало эффект.

В 2018 г., как и в 2016 г., отмечали наибольшее увеличение урожайности семян на варианте с применением минеральных удобрений вразброс под предпосевную культивацию в дозе $\mathrm{N}_{48} \mathrm{P}_{52}$. Прибавка по сравнению с контролем составила 0,24 т/га, или $25,5 \%$. На естественном фоне плодородия почвы эффективно применение биопрепарата Флавобактерин. Совместное применение минеральных удобрений и бактериальных препаратов, как и в предыдущие годы, уступало действию штамма Флавобактерин без удобрений.

В среднем за 2016-2018 гг. урожайность сафлора на контрольном варианте составила 1,03 т/га. От внесения минеральных удобрений вразброс под предпосевную культивацию в дозе $\mathrm{N}_{48} \mathrm{P}_{52}$ урожайность повысилась на 18,4 \%. Существенное повышение данного показателя во все годы исследований обеспечила обработка семян бактериальным препаратом Флавобактерин. В среднем за 3 года урожайность по сравнению с контролем была выше на 13,6 \%. Исследования показали, что сочетание применения штаммов азотфиксаторов на фоне азотно-
Урожайность сафлора, т/га

\begin{tabular}{|c|c|c|c|c|c|c|}
\hline \multirow{2}{*}{ Вариант } & \multirow{2}{*}{ 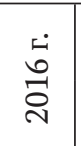 } & \multirow{2}{*}{$\begin{array}{l}\dot{1} \\
\text { 웡 }\end{array}$} & \multirow{2}{*}{$\begin{array}{l}\dot{1} \\
\infty \\
\stackrel{0}{\circ} \\
\dot{N}\end{array}$} & \multirow{2}{*}{ 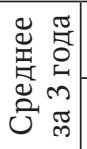 } & \multicolumn{2}{|c|}{$\begin{array}{l}\text { Прибавка } \\
\text { к контролю } \\
\end{array}$} \\
\hline & & & & & т/га & $\%$ \\
\hline Контроль & 0,92 & 1,11 & 0,94 & 1,03 & - & - \\
\hline \multicolumn{7}{|c|}{ Внесение минеральных удобрений при посеве } \\
\hline $\mathrm{N}_{24} \mathrm{P}_{26}$ & 1,01 & 1,23 & 1,05 & 1,09 & 0,06 & 5,8 \\
\hline $\mathrm{N}_{24} \mathrm{P}_{26} \mathrm{~K}_{24}$ & 1,01 & 1,22 & 1,06 & 1,09 & 0,06 & 5,8 \\
\hline $\mathrm{N}_{24} \mathrm{P}_{52}$ & 1,01 & 1,25 & 1,04 & 1,10 & 0,07 & 6,8 \\
\hline $\mathrm{N}_{48} \mathrm{P}_{52}$ & 0,96 & 1,21 & 0,94 & 1,04 & 0,01 & 0,9 \\
\hline \multicolumn{7}{|c|}{ Вразброс под предпосевную культивацию } \\
\hline $\mathrm{N}_{24} \mathrm{P}_{52}$ & 1,09 & 1,29 & 1,09 & 1,16 & 0,13 & 12,6 \\
\hline $\mathrm{N}_{48} \mathrm{P}_{52}$ & 1,18 & 1,31 & 1,18 & 1,22 & 0,19 & 18,4 \\
\hline $\mathrm{N}_{48} \mathrm{P}_{52} \mathrm{~K}_{48}$ & 1,08 & 1,37 & 1,08 & 1,18 & 0,15 & 14,6 \\
\hline $\mathrm{N}_{72} \mathrm{P}_{52}$ & 1,11 & 1,30 & 1,06 & 1,16 & 0,13 & 12,6 \\
\hline $\mathrm{N}_{72} \mathrm{P}_{52} \mathrm{~K}_{48}$ & 1,06 & 1,29 & 1,03 & 1,13 & 0,10 & 9,7 \\
\hline \multicolumn{7}{|c|}{$\begin{array}{c}\text { Внесение минеральных удобрений } \\
\text { и биопрепаратов при посеве }\end{array}$} \\
\hline КЛ-10 & 0,94 & 1,25 & 0,98 & 1,04 & 0,01 & 0,9 \\
\hline $\mathrm{N}_{24} \mathrm{P}_{52}+\mathrm{K} Л-10$ & 1,07 & 1,27 & 1,07 & 1,14 & 0,11 & 10,7 \\
\hline Мизорин & 0,95 & 1,20 & 1,01 & 1,05 & 0,02 & 1,9 \\
\hline $\mathrm{N}_{24} \mathrm{P}_{52}+$ Мизорин & 1,02 & 1,14 & 1,00 & 1,07 & 0,04 & 3,9 \\
\hline Флавобактерин & 1,12 & 1,25 & 1,14 & 1,17 & 0,14 & 13,6 \\
\hline $\mathrm{N}_{24} \mathrm{P}_{52}+$ Флавобактерин & 1,08 & 1,16 & 1,08 & 1,11 & 0,08 & 7,8 \\
\hline $\mathrm{HCP}_{05}$ & 0,09 & 0,10 & 0,07 & & 0,07 & \\
\hline
\end{tabular}

фосфорных удобрений неэффективно. Прибавка урожайности меньше по сравнению с контрольным вариантом, чем от действия штамма Флавобактерин на естественном фоне плодородия.

Оценивая действие минеральных удобрений, применяемых при посеве, установили, что во все годы существенного увеличения урожайности семян сафлора не было зафиксировано. Прибавка в среднем за 3 года составила лишь 0,05 т/га, или 4,8 \%. По-видимому, заделка минеральных удобрений в верхний слой почвы вразброс под предпосевную культивацию при условии хорошей влагообеспеченности способствовала интенсивному развитию корневой системы сафлора и более равномерному контакту с ионами почвенного раствора. Локальное размещение удобрений в рядки при посеве в условиях дефицита влаги оказало негативное влияние на рост и развитие растений и, в конечном итоге, на урожайность.

Содержание масла в семенах сафлора в годы проведения опытов 2016-2018 гг. изменялось незначительно на всех вариантах и составило 35,736,3 \% (табл. 2). Таким образом, изучаемые агрохимические приемы не влияли на содержание масла в семенах сафлора. На контрольном варианте сбор масла с 1 га в среднем за 3 года составил 337 кг.

Следует отметить очень широкий разброс прибавки сбора масла в урожае семян сафлора по вариантам опыта - от 22 до 80 кг/га. Основной причиной могут являться различия в урожайности семян, так как масличность при внесении минеральных удобрений и бактериальных препаратов существенно не изменялась. В среднем за три года максимальная прибавка получена при внесении минеральных удобрений вразбросподпредпосевную культивацию в дозе $\mathrm{N}_{48} \mathrm{P}_{52}$. Увеличение по сравнению с контроль- 
Влияние минеральных удобрений и бактериальных препаратов на масличность и сбор масла в урожае маслосемян сафлора

\begin{tabular}{|c|c|c|c|c|c|c|c|}
\hline \multirow{2}{*}{ Вариант } & \multirow{2}{*}{$\begin{array}{c}\text { Масличность, \%. } \\
\text { среднее за 2015-2017 гг. }\end{array}$} & \multicolumn{6}{|c|}{ Сбор белка, кг/га } \\
\hline & & 2016 г. & 2017 г. & 2018 г. & среднее за 3 года & приб & контролю \\
\hline Контроль & 36,0 & 305 & 368 & 339 & 337 & - & - \\
\hline \multicolumn{8}{|c|}{ Внесение минеральных удобрений при посеве } \\
\hline $\mathrm{N}_{24} \mathrm{P}_{26}$ & 36,3 & 335 & 413 & 381 & 376 & 39 & 11,6 \\
\hline $\mathrm{N}_{24} \mathrm{P}_{26} \mathrm{~K}_{24}$ & 35,9 & 337 & 397 & 380 & 371 & 34 & 10,1 \\
\hline $\mathrm{N}_{24} \mathrm{P}_{52}$ & 36,1 & 335 & 415 & 375 & 375 & 38 & 11,3 \\
\hline $\mathrm{N}_{48} \mathrm{P}_{52}$ & 35,7 & 314 & 399 & 345 & 353 & 16 & 4,7 \\
\hline \multicolumn{8}{|c|}{ Вразброс под предпосевную культивацию } \\
\hline $\mathrm{N}_{24} \mathrm{P}_{52}$ & 36,2 & 361 & 432 & 395 & 396 & 59 & 17,5 \\
\hline $\mathrm{N}_{48} \mathrm{P}_{52}$ & 36,0 & 389 & 435 & 427 & 417 & 80 & 23,7 \\
\hline $\mathrm{N}_{48} \mathrm{P}_{52} \mathrm{~K}_{48}$ & 35,1 & 347 & 444 & 380 & 390 & 53 & 15,7 \\
\hline $\mathrm{N}_{72} \mathrm{P}_{52}$ & 35,9 & 365 & 431 & 382 & 393 & 56 & 16,6 \\
\hline $\mathrm{N}_{72} \mathrm{P}_{52} \mathrm{~K}_{48}$ & 35,7 & 346 & 425 & 367 & 379 & 42 & 12,5 \\
\hline \multicolumn{8}{|c|}{ Внесение минеральных удобрений и биопрепаратов при посеве } \\
\hline КЛ-10 & 36,3 & 312 & \begin{tabular}{|l|}
420 \\
\end{tabular} & 356 & 363 & 26 & 7,7 \\
\hline $\mathrm{N}_{24} \mathrm{P}_{52}+\mathrm{K} Л-10$ & 36,2 & 360 & 417 & 390 & 389 & 52 & 15,4 \\
\hline Мизорин & 36,0 & 313 & 399 & 364 & 359 & 22 & 6,5 \\
\hline $\mathrm{N}_{24} \mathrm{P}_{52}+$ Мизорин & 36,3 & 341 & 381 & 387 & 370 & 33 & 9,8 \\
\hline Флавобактерин & 35,9 & 371 & 411 & 412 & 398 & 61 & 18,1 \\
\hline $\mathrm{N}_{24} \mathrm{P}_{52}+$ Флавобактерин & 36,2 & 360 & 388 & 390 & 379 & 42 & 12,5 \\
\hline $\mathrm{HCP}_{05}^{24}$ & $F_{\phi}<F_{\text {red }}$ & 33 & 31 & 26 & & 23 & \\
\hline
\end{tabular}

ным вариантом составило 23,7 \%. Штамм Флавобактерин в чистом в виде показал лучший результат по влиянию на сбор масла. Прибавка к контролю составила 51 кг/га, или 18,1\%.

Заключение. Для повышения урожайности семян сафлора и увеличения сбора масла в условиях северо-восточной зоны Ростовской области необходимо применять минеральные удобрений вразброс под предпосевную культивацию в дозе $\mathrm{N}_{48} \mathrm{P}_{52}$.

При посеве сафлора без минеральных удобрений целесообразно использовать бактериальный препарат Флавобактерин из расчета 300 г на гектарную норму.

\section{СПИСОК ЛИТЕРАТУРЫ}

1. Беляков А.М. Масличный «верблюд»// Поле деятельности. - 2013. - №10. - С. 68-71.

2. ГОСТ 28268-89 Почвы. Методы определения влажности, максимальной гигроскопической влажности и влажности устойчивого завядания растений // GostExpert.ru>gost/getDoc/41431.

3. ГОСТ 29269-91 «Почвы. Общие требования к проведению анализов» // GostExpert.ru>gost/ getDoc/41431.

4. Доспехов Б.А. Методика полевого опыта (с основами статистической обработки результатов исследований). - 5-е изд., перераб. и доп. - М.: Агропромиздат, 1985. - 351 с.

5. Зональные системы земледелия Ростовской области на 2013-2020 годы / С.Г. Бондаренко [и др.]. Ростов н/Д.: Донской издат. дом, 2013. - Ч. 2. - 243 с.

6. Каргин В. Есть ли перспективы у Зауральского рапса? // Нивы Зауралья. - 2012. - № 7. - С. 8-9.

7. Микробиологические препараты на основе клубеньковых и ассоциативных ризобактерий в сельском хозяйстве // Каталог микробиологических препаратов: ФГБНУ «Всероссийский научно исследовательский институт сельскохозяйственной микробиологии» [Электронный ресурс]. - Режим доступа: http:// permagrohim.ru/assets/files/ecos_katalog.pdf (дата обращения: 17.11.2017).

8. Минаков И. Развитие рынка масличных культур и растительного масла // АПК: экономика, управление. - 2013. - № 11. - С. 54-59.

9. Нарушев В.Б, Мажаев Н.И., Желмуханов Т.А. Разработка технологии возделывания сафлора на Саратовском левобережье // Главный агроном. 2015. - № 1-2. - С. 32-33.

10. Продуктивность севооборота и баланс питательных веществ при длительном внесении минеральных удобрений в степном Поволжье / В.В. Пронько [и др.] // Аграрный научный журнал. - 2017. - № 5. - С. 33-40.

11. Рябиева Н.А. Совершенствование элементов технологии возделывания сафлора в Ростовской области // Сельское, лесное и водное хозяйство. 2015. - № 3. - URL: http://agro.snauka.ru/2015/03/1853 (дата обращения: 07.02.2019).

12. Хрусталев Ю.П., Василенко В.Н. Климат и агроклиматические ресурсы Ростовской области. Ростов н/Д., 2002. - 179 с.

13. Шиков А.Н., Макаров В.Г., Рыженков В.Е. Растительные масла и масляные экстракты: технология, стандартизация, свойства. - М.: Русский врач, 2004. - 264 с.

14. Яриев Г.Ф., Байкасенов Р.К. Влияние способов посева и регулятора роста на урожайность маслосемян сафлора в условиях учебно-опытного поля ОГАУ // RUSSIAN AGRICULTURAL SCIENCE REVIEW. 2014. - № 3. - C. 132-137.

Разумнова Людмила Александровна, аспирант кафедры агрохимии и экологии им. Е.В. Агафонова, Донской государственный аграрный университет. Россия.

Каменев Роман Александрович, $\partial-p$ c.- $x$. наук, доиент кафедры агрохимии и экологии им. Е.В. Агафонова, Донской государственный аграрный университет. Россия.

Баленко Елена Георгиевна, канд.с.-х. наук, доцент, зав. кафедрой «Естественнонаучные дисииллины», Донской государственный аграрный университет. Россия. 
346493, Ростовская обл., Октябрьский (с) $p$-н, пос. Персиановский, ул. Кривошлыкова, 24.

Тел.: (86360) 3-51-50.
Ключевые слова: темно-каштановая почва; сафлор; урожайность; масличность; бактериальные препараты; минеральные удобрения.

\title{
THE EFFICIENCY OF FERTILIZERS AND BACTERIAL PREPARATIONS ON SAFFLOWER
} IN THE RISK FARMING AREA OF THE ROSTOV REGION

Razumova Lyudmila Alexandrovna, Post-graduate Student of the chair "Agrochemistry and Ecology named after E. V. Agafonov", Don State Agrarian University. Russia.

Kamenev Roman Aleksandrovich, Doctor of Agricultural Sciences, Associate Professor of the chair "Agrochemistry and Ecology named after E. V. Agafonov", Don State Agrarian University. Russia.

Balenko Elena Georgievna, head of the Department of, Candidate of Agricultural Sciences, Associate Professor, Head of the chair "Natural Sciences", Don State Agrarian University. Russia.

Keywords: dark chestnut soil; safflower; yield; oil content; bacterial preparation; mineral fertilizers.

The article presents the results of field experiments on the effect of mineral fertilizers and bacterial preparations on the yield and quality of safflower seeds. Studies were conducted in 2016-2018 in the North-Eastern zone of the Rostov region on dark chestnut soils. The object of research was the variety of safflower Zavolzhsky-1. Predecessor was winter wheat. As mineral fertilizers, ammonium nitrate and ammophos were used in various doses, according to the scheme of experience, which were introduced simultaneously with sowing or randomly for presowing cultivation. The bacterial preparations were presented to the associative nitrogen-fixing bacteria of the strains Minorin, Flavobacterium, $K L-10$ production research center of Pushkin. In the field experiment, the variants of the joint application of mineral fertilizers and pre-sowing treatment of seeds with bacterial preparations were also studied. The control was an option without the use of mineral fertilizers and bacterial preparations. The research methodology is standard for studying the action of fertilizers. The average seed yield of safflower on the options amounted to 1,03-1,22 $t / h a$, oil content of seeds of 35.9-36.3 percent, and the yield of oil yield of seeds from 1 ha- 337-398 kg. In the course of research, we have found that the optimal dose of mineral fertilizers, providing the greatest yield and yield of oil in harvest - introduction of scattering under the sowing cultivation at a dose of N48P52. The increase to the control variant was $18.4 \%$. The yield of oil was increased by $23.7 \%$. The bacterial preparation with associative strains of nitrogen-fixing bacteria for use on natural background fertility of the soil Flavobacterium was identified. The increase in the yield of oilseeds was $13.6 \%$, oil collection was $18.1 \%$.

\section{ПОСЛЕДЕЙСТВИЕ ГЕРБИЦИДОВ И ДИНАМИКА ИХ РАЗЛОЖЕНИЯ В РАЗЛИЧНЫХ АГРОЛАНДШАФТАХ}

\author{
СПИРИдОНОВ Юрий Яковлевич, Всероссийский научно-исследовательский институт \\ фитопатологии \\ БУДынков Николай Иванович, Всероссийский научно-исследовательский институт \\ фитопатологии
}

СТРИжкОВ Николай Иванович, ФГБНУ «НИИСХ Юго-Востока»

СУМИНОВА Наталья Борисовна, Саратовский государственный аграрный университет имени Н.И. Вавилова

САЙФУЛЛИНА Лариса Борисовна, ФГБНУ «НИИСХ Юго-Востока»

ЛЕНОВИЧ Дарья Рудольфовна, Саратовский государственный аграрный университет имени Н.И. Вавилова

СУЛТАНОВ Арман Сисенович, Саратовский государственный аграрный университет имени Н.И. Вавилова

Изложены результаты опытов по определению динамики разложения и остаточных количеств гербицидов в почве и в получаемой продукции в различных агроландшафтах. Установлено, что длительность сохранения гербицидов в почве, в первую очередь сульфонилмочевин, и связанный с этим уровень их отрицательного последействия на чувствительные культуры севооборота зависят от рельефа, типа почв, их физико-химических свойств, гидротермического режима среды и характера антропогенного воздействия на агроэкосистему.

Введение. Сельскохозяйственное производство невозможно без применения химических средств защиты растений (фунгицидов, гербицидов, инсектицидов и пр.) [5,8-11]. По многочисленным данным, вредные организмы наносят огромный ущерб сельскому хозяйству, поэтому с ними необходимо постоянно вести борьбу [1, 6, 7, 12-15]. Первое место в мире среди вредоносных факторов (представителей насекомых-вредителей, нематод и многочисленных возбудителей болезней), отрицательно влияющих на урожайность сельскохозяйственных культур, устойчиво занимают сорняки. Они являются постоянно действующим фактором, определяющим наиболее значимое уменьшение урожайности. Ежегодные потери в России из-за сорной растительности оценены почти в 40 млн т. Для эффективной борьбы с сорняками в настоящее время рекомендуются современные гербициды [2-4, 16-20].

Однако широкомасштабное применение современных гербицидов в практике борьбы с засоренностью посевов основных сельскохозяйственных культур без разработки научно обоснованных оптимальных технологий и регламентов их использования не безопасно из-за получения существенного нежелательного эффекта для агроценозов в целом, обусловленного слишком высокой фитотоксичностью загрязненных их остатками почв. 